Journal of Business and Management Research

ISSN: 2382-5219(Print); 2467-9267(Online)

January 2017, Vol.2, No. 1 \& 2, pp.14-32

(C) 2017 Kathmandu University

School of Management

DOI: http://dx.doi.org/10.3126/jbmr.v2i1-2.18149

\title{
Predictors and Outcomes of Employee Engagement: Empirical Study of Nepali
}

\section{Employees}

\author{
Sabina Baniya Chhetri* \\ School of Management, Kathmandu University, Lalitpur, Nepal
}

\begin{abstract}
Engaged employees are the most sought-after resources in organizations across the globe. Efforts have been made by academicians and management consultants to help organizations understand the dynamics of Employee Engagement. Little is known, though, about Employee Engagement and its predictors and outcomes in the context of Nepali organizations. This study examined the relationship between predictors and outcomes of Employee Engagement among employees of Nepali organizations and tested its mediating effects. The study was conducted among 158 employees working in various organizations. Correlation, multiple regression, and bootstrapping methods were used to test the hypothesized relationships. The results in general found support for all the hypothesized relationships between predictor variables, viz.: Person-Organization Fit (P-O), Perceived Organizational Support (POS), and Employee Engagement. Likewise, Employee Engagement and outcome variables: Job satisfaction, Organizational Citizenship Behavior (OCB) and Counterproductive Work Behavior (CWB) were related too. Employee Engagement fully mediated the relationship between P-O Fit and OCB, POS and OCB, and POS and CWB while partially mediated the relationship between P-O Fit and Job satisfaction, P-O Fit and CWB and POS and Job satisfaction. The findings are discussed and implications identified.
\end{abstract}

Keywords: Employee engagement, person-organization fit, perceived organizational support, job satisfaction, organizational citizenship behavior, counterproductive work behavior

\section{Introduction}

Organizations have been increasingly focusing their attention on the issue of a lack of engagement among employees in the workplace. Academic interest in it is, though, recent and limited. Therefore, arduous examination of the theory related to Employee Engagement is limited (Macey \& Schneider, 2008). This is compounded by the fact that findings of the study conducted by consulting firms and academia are at odds with each other. Many global consulting firms have reported different performance outcomes of Employee Engagement such as sales and revenue growth (Gallup, 2007; Towers Perrin, 2003), financial performance (Towers Perrin, 2003), managerial effectiveness (Harter et al., 2002; Luthans \& Peterson, 2002), reduced absenteeism (Gallup, 2004), reduced turnover (Towers Perrin, 2003), and more. However, academia does not agree with these consulting firms as these firms have not given proper attention towards conceptualizing the construct "Employee Engagement". In the lack of proper conceptualization, the outcomes that have resulted from their studies can be questioned. For

* Author Email: sabina@kusom.edu.np 
instance, Harter et al. (2002) from the Gallup defined Employee Engagement as "an individual ${ }^{\text {ee }} \mathrm{s}$ involvement and satisfaction with as well as enthusiasm for work" (p. 269). Similarly, many consulting firms have interchanged the definition of Employee Engagement with Job satisfaction, job involvement, organizational commitment and contextual performance. In the context of academia, Employee Engagement is an emerging concept and only working concepts have been proposed for testing. Also, in some empirical studies (e.g.; Saks, 2006; Macey \& Schneider, 2008; Rich et al., 2010; Biswas \& Bhatnagar, 2013), only limited number of predictors and outcomes of Employee Engagement have been identified.

Job characteristics, rewards and recoginition, perceived organizational support, person organization fit, core-self evaluation are some of the constructs that are considered as predictors of Employee Engagement by various research studies (Hakanen et al., 2006; Saks, 2006; Xanthopoulou et al., 2007; Rich et al, 2010; Biswas \& Bhatnagar, 2013). Less is known about other possible factors that predict Employee Engagement (Saks, 2006). Moreover, even though some models do reflect the relationship between Employee Engagement and its outcomes, many of them do not explain the relationship through theoretical basis (Macey \& Schneider, 2008).

Thus, Employee Engagement as a construct needs rigorous investigation and requires a foundational theoretical model to help understand it better so that organizations can base their application on it. In addition, the construct requires expansion in terms of its relation with its predictors and outcomes. In the context of Nepal, the first-hand understanding about the construct as well as its predictors and outcomes would be helpful for Nepali organizations as there are no relevant studies that the Nepali organizations can refer to, for understanding the context of Employee Engagement and take maagerial decisions about it.

In the current context, technologies and innovative products/services in the market can be copied by competitors within the short period of time but highly engaged human resource cannot be imitated and they bring unequaling competitive advantage to the organization. The questions for today's Nepali organizations are: How to generate an engaged workforce? What are the outcomes that can be expected from an engaged workforce? Will Employee Engagement mediate the relationship between predictors and outcomes in the context of Nepali organizations?

\section{Theoretical Background}

\section{Employee Engagement}

Much of what has been discussed about Employee Engagement exist in studies published by consulting firms where it has its source in practice rather than theory and empirical research (Saks, 2006). Interestingly, even though the construct is popular among organizations, it did not receive needed attention till the recent time from academia.

The definition coined by the consulting firms varied and could not be distinguished from other defined constructs. The definitions and measures used are comparable to constructs like organizational commitment and organizational citizenship behavior (Robinson et al., 2004). More frequently, it has been defined as the amount of at will effort displayed by employees at their job(Frank, Finnegan, \& Taylor, 2004). 
Kahn (1990) defined personal engagement as the utilization of employees's selves to their work roles such that they employ and express themselves physically, cognitively, and emotionally during their job role performance.. Maslach \& Leiter (1997) stated that "engagement" is categorized in terms of energy, involvement and efficacy. These researchers further theorized engagement as reverse of the three burnout dimensions:exhaustion, cynicism, and absence of professional efficacy. And Schaufeli et al. (2002) defined engagement as a work-related state of mind that is positive as a positive and rewarding and is work-related state of mind that is categorized as vigor, dedication, and absorption.

Even though, in academia, engagement has been suggested to be related to other different types of variables of organizational behavior as job involvement, organizational commitment, and job satisfaction, it is conceptualized as a distinct construct. Therefore, concept of engagement should be differentiated from organizational commitment, job involvement and Job satisfaction. Saks (2006) pointed out that organizational commitment is an employees' attitude and the attachement they have towards the organization while engagement is not an attitude rather a degree to which employee is fully observant and engrossed in the performance of their roles. And, job involvement one's self-image (May et al., 2004).

With that understanding, the construct has been defined by Saks (2006) as a unique construct which is distinct from other variables and that that entails dimensions as; cognitive, emotional, and behavioral which are associated with individual role performance. The definition provided by Saks is developed from the Kahn's theory on Employee Engagement. Kahn (1990) gave comprehensive conceptualization to the construct engagement. According to his conceptualization, Employee Engagement is visible when employees are physically involved in tasks either individually or in team, are cognitively alert, focused and attentive and are emotionally attuned to their work. This study also embraces the operational definition provided by Kahn's conceptualization of engagement .

\section{Predictors of Employee Engagement}

Although less is known about the factors that predict Employee Engagement, it is feasible to identify number of important predictors from Kahn's (1990) model (Saks, 2006).

This study builds upon Kahn's conceputalization of engagement as a distinct and unique and vital motivational concept: the utilization of an employee's complete self in terms of physical, cognitive, and emotional energies to work role performances. May et al. (2004), conducted a study to empirically test Kahn's (1990) model in which meaningfulness, safety, and availablity were found to be significantly related with engagement. Further, same study stated that role fit and job enrichment were the predictors of meaninfulness while rewarding employees and presence of supportive superviors towards employees were predictors of safety (Saks, 2006). Therefore, this study also considers Person-Organization Fit (P$\mathrm{O}$ fit) and Perceived organization support (POS) as predictors of Employee Engagement.

\section{Person-Organization Fit (P-O Fit)}

In Kahn's purposed model, one essential impact of meaningfulness is the fit between the work behaviors expected by an organization and work behaviors that individual employees consider valuable as a part of their own self-images. More specifically, when employees see that their roles demand for behaviors that are consistent with what they perceive of themselves then only they consider the role valuable and are fully engaged in performing it (Rich et al, 2010).

Kristof (1996) defined P-O fit as "the compatibility between people and organizations that occurs when (a) at least one entity provides what the other needs, or (b) they share similar fundamental 
characteristics, or (c) both" (p. 4-5). The definition mentions both the supplementary and complementary fit. The first section of Kristof's conceptualization refers to complementary fit that also comprises of demand-abilities (DA) fit and need-supplies (NS) fit. As proposed in the Kahn's model, the study holds the definition of P-O fit as fit between behaviors expected by an organization and behaviors that individual employees value which is what Kristof (1996) stated in their definition. Investigators of this construct states that $\mathrm{P}-\mathrm{O}$ fit is essential for sustaining the flexible and committed workforce in business scenario that is competitive in terms of earning revenue as well as labor market that supplies competent work-force (Bowen, Ledford \& Nathan, 1991; Kristof, 1996).

When individual perceived positivity in the work environmnent, he or she tends to show positive behavior. Therefore, when the employees perceived their fit with their organization, they tend to perform their job effectively and efficiently by fully engaging towards their job roles (Hamid \& Yahy, 2011). P$O$ Fit enhances the sense of pyschological safety among employees which is why it has been identified as a predictors in Kahn's model of engagement and by other reseachers (e.g. Rich et al, 2010, Biswas \& Bhatnagar, 2013) for empirical test. This study also considered P-O fit as predictors of Employee Engagement and will measure subjective P-O fit perceptions. Therefore, the first hypothesis is as follows:

H1: P-O fit is positively related to Employee Engagement.

\section{Perceived Organizational Support (POS)}

Perceived Organizational Support (POS) is universal belief that organization values its employees's contribution through their work and exhibts care towards their well-being (Rhoades \& Eisenberger, 2002). Kahn (1992) states that sense of psychological safety is integral to POS. According Kahn, Psychologial safety encompasses a sense of being that helps in expressing and employing the self without negative penalties to self-image, status or career. If employees sense organizational support towards their work and well-being then they become more engaged in their job and work for the overall achievement of organizational goals. Kahn suggested that employees experience psychological safety as a result of supportive environment, support and trust filled interpersonal relationships with others in their organization. Individuals who experiences supporting and trusting interpersonal relationships as well as supportive organizations are able to face risks, be their real selves, try and if even failed, do not fear consequences (Kahn, 1990). When employees experience higher organizational support then employees have positive and known expectations regarding organization's probable reaction to employees' contribution. Also, organization will be more accepting towards the mistakes. Hence, they invest entirely into their job roles (Edmondson, 1999).

Further, when POS is low, employees are not sure of what they should expect in their job roles, they fear that they may suffer for being engaged in their job roles, and choose to protect their selves by peforming limited in their roles (Kahn, 1990). This study adopts the definition purposed by Kahn and so POS is considered as a predictor of Employee Engagement in this study. Therefore, the second hypothesis is.

$\mathrm{H} 2$ : POS is positively related to Employee Engagement.

\section{Outcomes of Employee Engagement}

The concept Employee Engagement is popular because it is believed to have positive work performance outcomes (e.g. Job satisfaction, organizational citizenship behavior, and organizational commitment). for organizations. The impact of disengagement can be evident in organizations in terms of revenue 
mesaures and Return On Investement (ROI) and so on. Further, Biswas \& Bhatnagar (2013) stated that engaged employees, who experienced pleasant emotional state at work, indicated high level of satisfaction in their job. This study tried to relate job performance and Job satisfaction as outcomes of Employee Engagement, job performance was defined as the set of behaviors that is accumated worth to an organization which an employee contributes both directly and indirectly in achieveing organizational goals (Campbell, 1990, Borman \& Motowidlo, 1993).

\section{Employee Engagement and Contextual Performance}

Contextual Performance has been expressed through different terms by different researchers as; citizenship behaviors (Smith, Organ, \& Near, 1983), prosocial behaviors (Brief \& Motowidlo, 1986), and extra-role behaviors (George \& Brief, 1992). Recently, Sackett (2002) suggested that a negative dimension of job performance should be added to the framework of performance i.e. counterproductive work behaviors. This resulted into a broad three-dimensional conception of job performance: task performance, contextual performance, and counterproductive behaviors. However, this study only tried two dimensions of job performance; contextual performance and counterproductive behaviors as outcome variables of Employee Engagement.

Contextual Performance is not the direct peformance as it is considered as developing behaviors that contributes to organization but indirectly (Borman \& Motowidlo, 1997). These types of behaviors usually fosters a social and psychological environment beneficial to the accomplishment of work activities involved in the organization's core work (Ariani, 2013). When employees devote energy into their work roles, they should exhibit higher contextual performance leading to their behaving in a way that enriches the social and psychological context of the organization (Borman \& Motowidlo, 1997). Further, engagement is assumed to be a measure of employee willingness to spend voluntary and willing effort.

There are two performance related behaviors that is beyond the job description or the assigned activities of the employees: the positive and negative behaviors (Miles, Spector, Borman, \& Fox, 2002). On the positive side, researchers have considered voluntary behavior that have positive impact on the core activities done by employees, which is referred as Organizational Citizenship Behavior (OCB) or generally known as contextual performance. OCB is that type of positive voluntary behavior that don't contribute directly to the core activities in organization but supports by fostering enriching environment that additionally supports in achieveing organizational activities (Ariani, 2013). The study combinely includes both the Organizational Citizenship Behavior Organization (OCBO) and Organizatioan Citizenship Behavior Individual (OCBI) from the employees' perspective. On the negative side, the study has included negative act or behaviors which is destrucitve in nature as they destroys enriching environment in the organization and ultimately leading to ineffective (Ariani, 2013). OCB has been theorized as a positve peformance behavior that improves the operations of organizations (Organ \& Paine, 1999); whereas CWB is defined as negative employee behavior that damages or expected to damage, the authentic interests of an organization (Dalal, Lam, Weiss, Weich, \& Hulin, 2009). It is assumed that employees who behaviors exhibt OCB are unlikely to exhibit CWB and vice-versa. More specifically, CWB is harmful to other employees and organization (Lee \& Allen, 2002).

Employee Engagement has been observed as a potential antecedent of OCB in several studies (Rich et al.,2010; Chhetri, 2017)). Employees who are engaged may perform OCB because has both construct relates through the emotional component that exist in both (Bennett \& Robinson, 2000). This relationship is consistent with theoretical models which suggests that extra role behavior exhibition is cuased by their emotion (Miles et al., 2002). Employees who are highly engaged in their jobs are more 
likely to be involved towards voluntary extra role activities that necessarily are not asked by the organization. Similarly, employees who are less engaged do not much care about losing jobs or even engaging in harmful activities. Thus, the third fourth hypotheses are;

H3: Employee Engagement is positively related to OCB.

H4: Employee Engagement is negatively related to CWB.

\section{Employee Engagment and Job satisfaction}

Job satisfaction is a pleasant attitude or rewarding emotional state that is generally the result of an employee's job (Ugboro and Obeng, 2000). According to Hagedorn (2000), when a employee experience higher level of attainment, is deeply involved, , and is suitably compensated through financial and non-financial rewards, job satisfaction is visible and at times enhanced. Employees who are highly engaged in their job, experience higher level of job satisfaction as an engaged employees they are physical, mentally and emotionally involved in their work resulting in higher attainment which enhances job satisfaction. Furthermore, Hagedorn also pointed out that Job satisfaction predicted Employee Engagement. In his study, engagement is perceived as the result of Job satisfaction. Further, employees with low levels of satisfaction may be disengaged and not excited about contributing towards achieving organizational goals (Hagedorn, 2000).

Therefore, Job satisfaction has been not only considered as outcome of Employee Engagement but also predictor of employee engagment. However, this study considers Job satisfaction as an outcome of Employee Engagement. Thus, the fifth hypothesis is;

H5: Employee Engagement is positively related to Job satisfaction.

\section{Mediating Role of Employee Engagement}

The study tries to establish relationships between predictor and outcome variables in order to examine the mediating effect of Employee Engagement.

The study has reasoned that P-O Fit, POS stimulate utilization of cognitive, emotional, and physical energy into job role and that in turn converts into higher work performance outcomes. Those outcomes may be seen as Job satisfaction, organizational citizenship behavior, and lower counterproductive work behavior (Rich et al., 2010). In other words, Employee Engagement mediates the relationship between predictors and outcomes. In their study, Rich et al., (2010) found evidences that Employee Engagement mediated the relationship between POS and CSE with task performance and OCB. Thus, the study hypothesized the mediating effect of Employee Engagement among the relationship between predictors (P-O Fit and POS) and outcomes (job satisfaction, OCB and CWB). Thus, the sixth hypotheses are;

H6: Employee Engagement mediates the relationship between (a) P-O fit and OCB, (b) P-O Fit and CWB, (c) P-O Fit and Job satisfaction

H7: Employee Engagement mediates the relationship between (a) POS and OCB, (b) POS and CWB and (c) Job satisfaction

\section{Conceptual Framework}

The variables of this study are P-O Fit, POS (independent variables), Employee Engagement (mediating variable) and Job satisfaction, OCB, and CWB (dependent variables). These are depicted in the research framework in Figure 1. 


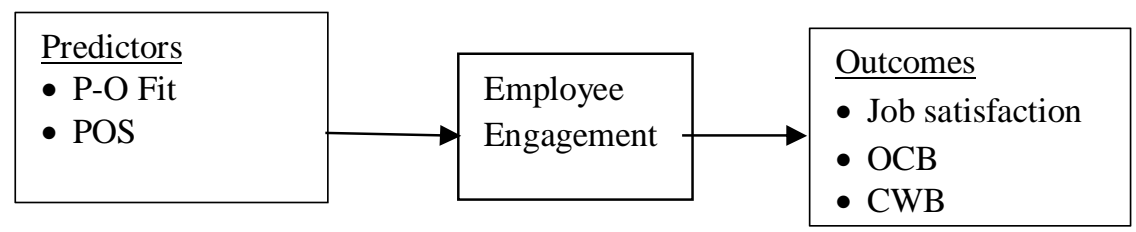

Figure 1. Conceptual Framework

\section{Methods}

\section{Research Design}

Descriptive research design was used in the study employing a self-reported questionnaire technique. The study was non- experimental and cross-sectional in the context of time horizon. The unit of analysis was individual and convenient sampling method was used. The sample size was determined through online calculator as 400 when the exact population size was unknown. 400 represented full time employees working in Nepali private and public organizations located in Kathmandu. The private and public organizations comprised of manufacturing organizations, privately owned software companies, finance companies, commercial banks, government banks, telecommunication companies. The study distributed total 600 questionnaires for this study to increase the response number of the study. Out of 600 questionnaires, 400 were distributed in these organizations while 200 online Google doc questionnaires were sent to different email addresses and also through social media. The email address was identified through snowball convenience sampling method. One respondent was sent an email and requested to send the questionnaire to others in the same organizations for online survey. Out of 600 questionnaires, 100 were received through online while 70 paper questionnaires were received. Among, 170 questionnaires, 12 questionnaires were not usable. Thus, 158 responses were considered in this study. The response rate was 40 percent. Annex - 1 provides a complete list of questions.

\section{Measures}

P-O Fit: The independent variable P-O Fit was measured using the three items developed by Cable and Judge (1996). The responses to these scales were measured on a 5-point scale ( $1=$ Strongly Disagree to $5=$ Strongly Agree). A sample item of the scale was "I feel that my personal values are a good fit with this organization".

POS: Another independent variable, POS rated by the respondents in 5-point scale comprised of an 8item scale. The scale was developed by Eisenberger and colleagues (Eisenberger et al., 1986). A sample item of this scale was "My organization really cares about my well-being".

These POS and P-O Fit variables are also considered as predictors of Employee Engagement.

Employee Engagement: The independent and mediating variable, Employee Engagement was measured by 18- item scale that was used by Rich et al., (2010) by revising popular Utrecht Work Engagement (UWES; Schaufeli \& Baker, 2003). The sample item of the scale was, "I devote lot of energy to my job."

OCB: OCB combinely measured both OCBI (Organizational Citizenship Behavior Individual) and OCBO (Organizational Citizenship Behavior Organization). The study used self-rating for the combined 
5-point scale (1= Never, $2=$ Seldom, $3=$ Sometimes, $4=$ Often and 5= Always). The sample item of the scale was, "Help others who have been absent."

CWB: CWB was measured by scale developed by Spector and colleagues and this study only tested items related to production deviation and withdrawal component in the sacle developed by Spector and Fox (2002). The sample item of the 5- point scale (1= Never to 5= Always) was, "Stayed home from work and said you were sick when you weren't".

Job satisfaction: Job satisfaction was measured by 3-item scale (Cammann et al. 1979). The sample item of the scale was, "All in all, I am satisfied with my job."

$\mathrm{OCB}, \mathrm{CWB}$ and job satisfaction were dependent variables and outcomes of Employee Engagement. Items for all scales used in the study are listed in the Appendix-1.

Reliability analyses were performed using Cronbach's Alpha for each instrument in order to determine that these instruments could be considered as measures of different variables under investigation in the Nepali organizational context.

To test the direct relationships between study variables, correlation coefficients were calculated. The correlation coefficients were used to examine whether the hypothesized direct relationships were significant and in the expected directions. Further, regression analysis was carried out to confirm the relationships indicated by the correlation coefficients.

Altogether five regression models were estimated taking P-O fit and POS as predictor variables, Employee Engagement as independent variable and contextual performance as OCB, CWB and Job satisfaction as work attitude. For the testing the mediating effects of Employee Engagement on predictors and outcome variables relationship, bootstrapping method (Hayes, 2009) was used.

\section{Results}

The demographic profile of respondents showed that 52.5 percent of the respondents were male and 47.5 percent were female, with a collective average age of the 30.16 years. Table 1 reports descriptive statistics and correlations and Cronbach's alpha among all study variables. As shown in the table, the study variables all have an adequate degree of internal consistency reliability. Further, Employee Engagement is related with the predictors and outcomes in the way that the study theorized. That is, respondents who higher level of fit with organization and perceived required organizational support were reported they were more engaged in their work. Also, respondents reporting higher level of engagement tended to exhibit higher Job satisfaction, OCB and lower CWB. Even though correlations are significant and provide initial support for our testable assumptions, multiple regression analysis was conducted to further see the effect of predictor variables on Employee Engagement and effect of Employee Engagement on outcome variables.

\section{Relationship between P-O Fit, POS with Employee Engagement, OCB, CWB and Job satisfaction}

The study used multiple regression to examine the degree to which P-O Fit and POS were related to Employee Engagement, OCB, CWB and Job satisfaction, and to see whether Employee Engagement mediated the relationship between P-O Fit and POS with OCB, CWB and Job satisfaction. The standardized regression estimates presented in Table 2 showed the direct association between the study variables. 
Table 1

Mean, Standard Deviation, Correlation matrix, and Cronbach's alpha

\begin{tabular}{lcccccccc}
\hline Variables & Mean & SD & 1 & 2 & 3 & 4 & 5 & 6 \\
\hline P-O Fit & 3.32 & 0.46 & $(.75)$ & & & & & \\
POS & 3.23 & 0.67 & $.49 * *$ & $(.80)$ & & & & \\
Employee & 4.11 & 0.63 & $.43^{* *}$ & $.39 * *$ & $(.95)$ & & & \\
Engagement & & & & & & & & \\
Job satisfaction & 3.83 & 0.80 & $.59 * *$ & $.50 * *$ & $.64 * *$ & $(.76)$ & & \\
OCB & 3.92 & 0.46 & $.23 * *$ & $.23 * *$ & $.34 * *$ & $.25 * *$ & $(.65)$ & \\
CWB & 1.53 & 0.56 & $-.34 * *$ & $-.23 * *$ & $-.37 * *$ & $-.44^{* *}$ & $-.40^{* *}$ & .79 \\
\hline
\end{tabular}

Notes: $* * p<.01$, Cronbach's alpha in the diagonal

As can be seen, Employee Engagement is associated positively and significantly with P-O Fit (standardized $\beta=0.36, \mathrm{R}^{2}=0.23, \mathrm{p}<0.01$ ) and POS (standardized $\beta=0.41, \mathrm{R}^{2}=0.25, \mathrm{p}<0.01$ ). This is consistent with Hypotheses 1 and 2 . The standardized regression coefficients for the relationships are selected by $\beta$. Further, OCB (standardized $\beta=0.29, \mathrm{R}^{2}=0.13, \mathrm{p}<0.01$ ), CWB (standardized $\beta=-0.49$, $\mathrm{R}^{2}=0.17, \mathrm{p}<0.01$ ) and job satisfaction (standardized $\beta=0.59, \mathrm{R}^{2}=0.43 \mathrm{p}<0.01$ ) are significantly related with Employee Engagement. The association of OCB and job satisfaction with Employee Engagement is positive while the association of CWB is negative. Consequently, we accept Hypotheses 3, 4 and 5.

Table 2

Regression Estimates

\begin{tabular}{lcccc}
\hline Model & $\beta$ (Standardized) & $\mathrm{R}^{2}$ & $\mathrm{~F}$ & Remarks \\
\hline P-O Fit $\rightarrow$ Employee Engagement & $0.36^{* *}$ & 0.23 & $12.79^{* *}$ & $\mathrm{H} 1$ accepted \\
POS $\rightarrow$ Employee Engagement & $0.41^{* *}$ & 0.25 & $14.05^{* *}$ & $\mathrm{H} 2$ accepted \\
Employee Engagement $\rightarrow$ OCB & $0.29^{* *}$ & 0.13 & $6.41^{* *}$ & $\mathrm{H} 3$ accepted \\
Employee Engagement $\rightarrow$ CWB & $-0.49 * *$ & 0.17 & $8.80^{* *}$ & H4 accepted \\
Employee Engagement $\rightarrow$ Job satisfaction & $0.59^{* *}$ & 0.43 & $30.45^{* *}$ & H5 accepted \\
\hline
\end{tabular}

Note: $* * p<.01$

\section{Mediating Effect of Employee Engagement on P-O Fit and Job satisfaction}

First, it was found that P-O Fit was positively associated with Employee Engagement $(\beta=.36, t(157)=$ $5.44, p<.01)$. It was also found that P-O Fit was positively related to Job satisfaction $(\beta=.64, t(157)=$ $6.95, p<.01)$. Lastly, results indicated that the mediator, i.e. Employee Engagement, was positively related with Job satisfaction $(\beta=.55, t(157)=6.95, p<.01)$. Because the study found both a-path and b-path to be significant, mediation analyses were tested using the bootstrapping method with biascorrected confidence estimates (MacKinnon, Lockwood \& Williams, 2004; Preacher \& Hayes, 2004). In this study, the 95 percent confidence intervals of the indirect effects were attained with 5000 bootstrap resamples (Preacher \& Hayes, 2008). Results of the mediation analysis established the mediating role of Employee Engagement in the relation between P-O Fit and Job satisfaction $(\beta=.198 ; \mathrm{CI}=.12$ to .31$)$. 
Moreover, results indicated that the direct effect of P-O Fit on Job satisfaction became significant $(\beta=$ $.44, t(157)=6.3, p<.01)$ when controlling for Employee Engagement, thus suggesting partial mediation. Figure1 displays the results, showing the direction of mediation.

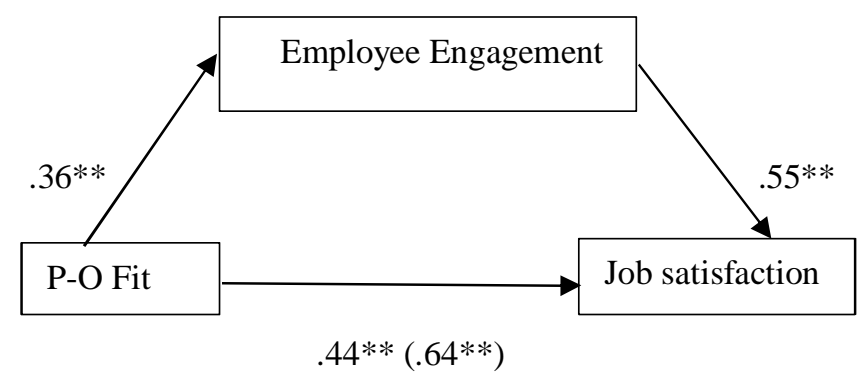

Figure 2. Indirect effect of P-O Fit on Job satisfaction through Employee Engagement

Mediating Effect of Employee Engagement on P-O fit- $O C B$

It was also found that P-O Fit was positively related to OCB $(\beta=.13, t(157)=2.97, p<.01)$. Lastly, results indicated that the mediator, i.e. Employee Engagement, was positively associated with $\mathrm{OCB}(\beta=$ $.19, t(157)=2.97, p<0.01)$. Results of the mediation analysis established the mediating role of Employee Engagement in the relation between P-O Fit and OCB ( $\beta=.07$; $\mathrm{CI}=.02$ to .14$)$. Moreover, results indicated that the direct effect of P-O Fit on OCB became significant $(\beta=.06, t(157)=1.04, p=$ .3) when controlling for Employee Engagement, thus suggesting full mediation. Figure 2 displays the results, showing the direction of mediation.

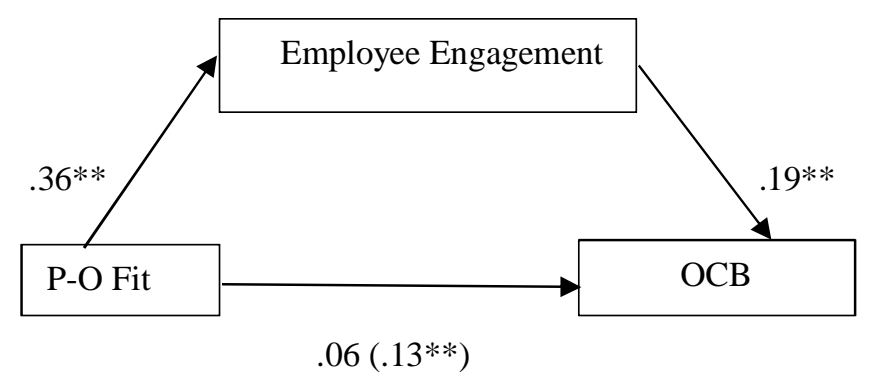

Figure 3. Indirect effect of P-O Fit on OCB through Employee Engagement

\section{Mediating Effect of Employee Engagement on P-O fit- CWB}

It was also found that P-O Fit was negatively related to CWB $(\beta=-.24, t(157)=-3.9, p<.01)$. Lastly, results indicated that the mediator, Employee Engagement, was negatively associated with CWB $(\beta=-$ $.18, t(157)=-2.5, p<.05)$. Results of mediation analysis established the mediating role of Employee Engagement in the relationship between P-O fit and CWB $(\beta=-.07$; CI $=-.14$ to -.009). Moreover, results indicated that the direct effect of P-O fit on CWB became significant at 5\% confidence interval 
$(\beta=-.17, t(157)=-2.6, p<.05)$ when controlling for Employee Engagement, thus suggesting partial mediation.

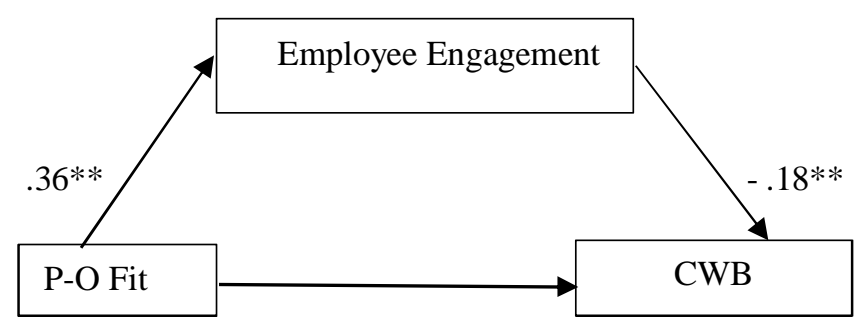

$-.17 * *(-.24)$

Figure 4. Indirect effect of P-O Fit on CWB through Employee Engagement

Mediating Effect of Employee Engagement on POS-Job satisfaction

It was also found that POS was positively related to Employee Engagement $\left(\beta=.39, t(157)=5.87, p^{<}\right.$ $.01)$. It was also found that POS was positively related to job satisfaction $(\beta=.63, t(157)=8.39, p<$ $.01)$. Lastly, results indicated that the mediator, Employee Engagement, was positively associated with Job satisfaction $(\beta=.55, t(157)=6.74, p<.01)$. Results of mediation analysis established the mediating role of Employee Engagement in the relationship between POS and Job satisfaction $(\beta=.21 ; \mathrm{CI}=.13$ to .32). Moreover, results indicated that the direct effect of $\mathrm{P}-\mathrm{O}$ fit on $\mathrm{CWB}$ was significant $(\beta=.42, t(157)$ $=5.713, p<.01)$ when controlling for Employee Engagement, thus suggesting partial mediation.

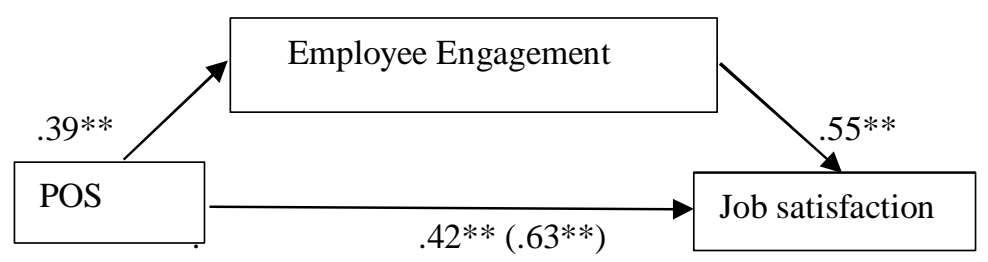

Figure 5. Indirect effect of POS on Job satisfaction through Employee Engagement

\section{Mediating Effect of Employee Engagement on POS-OCB}

It was also found that POS was positively related to $\operatorname{OCB}(\beta=.17, t(157)=6.95, p<.01)$. Lastly, results indicated that the mediator, Employee Engagement, was positively associated with OCB $(\beta=.17, t(157)$ $=3.41, p<.05)$. Results of mediation analysis confirmed the mediating role of Employee Engagement in the relationship between POS and $\mathrm{OCB}(\beta=.064 ; \mathrm{CI}=.014$ to .133$)$. In addition, results indicated that the direct effect of POS on OCB became non-significant $(\beta=.10, t(157)=.18, p<.10)$ when controlling for Employee Engagement, thus suggesting full mediation. 


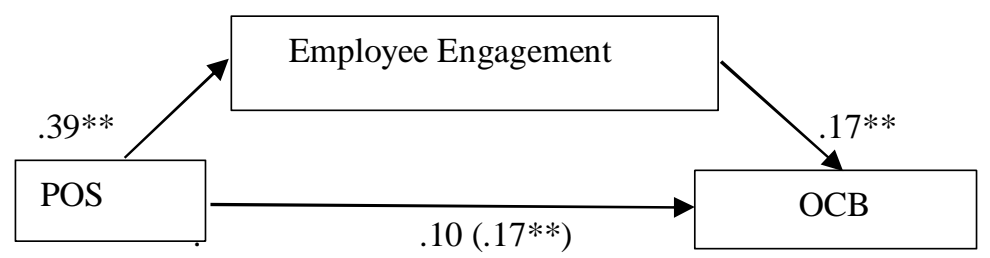

Figure 6. Indirect effect of POS on OCB through Employee Engagement

\section{Mediating Effect of Employee Engagement on POS-CWB}

It was also found that POS was negatively related to CWB $(\beta=-.21, t(157)=5.87, p<.01)$ Lastly, results indicated that the mediator, Employee Engagement, was negatively associated with CWB $(\beta=-$ $.2, t(157)=-2.61, p<.01)$. Results of mediation analysis established the mediating role of Employee Engagement in the relationship between POS and CWB $(\beta=-.08 ; \mathrm{CI}=-.15$ to -.011). Moreover, results indicated that the direct effect of POS on CWB became non-significant $(\beta=-.13, t(157)=-1.9, p=.3)$ when controlling for Employee Engagement, thus suggesting full mediation. Figure 7 displays the results.

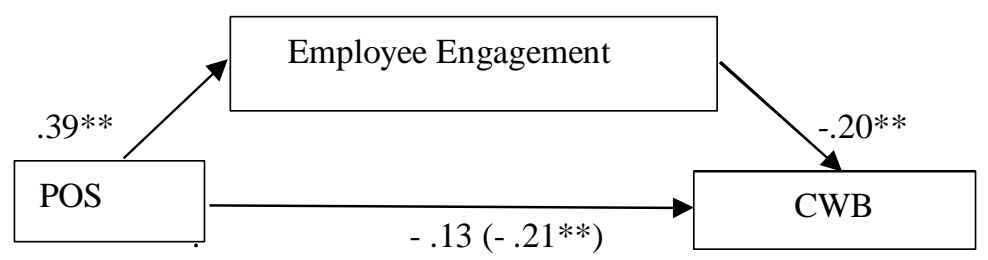

Figure 7. Indirect effect of POS on CWB through Employee Engagement

\section{Discussion}

The study examined the effect of predictor variables P-O Fit and POS on Employee Engagement and the effect of Employee Engagement on Job satisfaction and contextual performances. Further, the study also tested the mediating effect of Employee Engagement on the relationships between its predictor and outcome variables.

It found that P-O fit is positively associated with Employee Engagement which clearly indicated that employees' perception of their fit with organization positively affects their engagement in the organization. This finding is consistent with the finding of several studies (e.g., Rich,et al, 2010; Hamid \& Yahy, 2011; Biswas \& Bhatnagar, 2013). The P-O Fit relates to having fit between personal values and organizational values which exhibits through the sense of understanding of the organizational goals. Employees further exhibit clarity in the role conceptualization which results in higher engagement in the job. Similarly, when organizations observe employees with role understanding, they tend to commend responsibilities and offer necessary support. Hence, P-O Fit acts as a predictor of Employee Engagement. Additionally, fosters the possibility of support necessary to perform. 
This study also indicated positive relationship between POS and Employee Engagement which is consistent with several previous studies (e.g,Chhetri, 2017; Rich at al., 2010; Kralj \& Solnet, 2011). Biswas \& Bhatnagar (2013) suggested that organizations need to go beyond the specified contractual relationship and offer employees with economic and psychological support in order to extract optimum efforts. Employees when sense a backing from organization tend to come up with creative ideas, take initiation and are not hesitant to speak up their mind for organizational performance. Thus, employees who are focused in contributing and broadening their horizon of their job roles are engaged employees. So, POS is also a predictor of Employee Engagement. Employees when engaged in their job roles affect the performance outcomes of the organization.

Employee Engagement was found to be positviely associated with outcomes (e.g. Saks, 2006; Rich et al., 2010; Rurkkhuma \& Bartlettb, 2012; Ariani, 2013; Mathumbu \& Dodd, 2013; Chhetri, 2017). These studies found that Employee Engagement is a strong predictor of OCB. It is of the view that engaged employees perform extra role behavior because they are efficient at achieving goals which supports them with time to focus on organizational aspects that particularly is not demanded by organization. In addition, Ariani (2013) also found a significant negative relationship between Employee Engagement and CWB. Sulea,et al ( 2012) found a relationship between Employee Engagement, OCB and CWB. Kahn (1990) stated that employees who are highly disengaged in their work roles withhold their physical, cognitive, and emotional energies, and this is reflected in task activity that is at best, robotic, passive and detached. Further, they are least concern about organizational well-being. The counter-productive work behaviors not only hampers the culture in organization but also directly affects the task performance. Thus, engaged employees are asset in maintaining appropriate culture and avoiding counterproducitve work behaviors. In the context of Job satisfaction, the study (e.g Biswas \& Bhatanagar, 2013) found job satisfaction as the outcome of engagement while study (e.g. Hagedorn, 2000) have tested job satisfaction as predictor of Employee Engagement. As an outcome of this study, it can be stated that when employees experience engagement, they find their work more fulfilling and motivating which provides them a pleasant work environment.

Numerous past studies (e.g. Saks, 2006; Rich et al., 2010; Sulea, et al, 2012; Biswas \& Bhatanagar, 2013; Chhetri, 2017) have identified Employee Engagement as mediating construct. For instance, Sulea et al (2012) found that Employee Engagement partially mediated the relationship between POS and OCB and POS and CWB, but the mediating effect was stronger for OCB than CWB. Thus, the result consistent with the findings of previous studies too suggest that P-O Fit and POS will affect Employee Engagement which in turn will affect OCB and Job satisfaction positiviely and CWB negatively.

As hypothesized and in line with the findings of previous empirical studies, this study has established linkages between predictor variables (P-O fit, POS) and Employee Engagement and Employee Engagement and outcome variables (Job satisfaction, OCB and CWB) in Nepali organizational setting.

\section{Implications and Directions for Future Research}

This study builds on the Employee Engagement construct given by Kahn (1990) and further supports Saks (2006) view that engagement models need the psychological conditions or antecedents that is necessary for engagement as the previous studies lacked the pre-condition or predictors for Employee Engagement. There have studies considering the views of Saks and predictors and outcomes variables have been identified. This study also has identified P-O Fit and POS as predictors of Employee Engagement and Job satisfaction and OCB as outcomes of employment. In addition, this study also adds 
negative outcome as CWB as outcome variable. Additionally, this study adds an important construct CWB to the model of Employee Engagement which has not been observed through empirical evidences in the previous studies.

In context of Nepal, this study represents an initial inquiry into the effects of Employee Engagement. The result of this study suggests that Employee Engagement is an important construct that needs to be carefully looked at even Nepali organizational settings. There are several sectors and variables as human resource practices, job involvement, and turnover intention could also be analyzed in the future research.

This study provides importance of Employee Engagement, its predictors: P-O fit, POS and outcomes variables: Job satisfaction, OCB and CWB in Nepali context because it can helpHR practioners and organizational leaders to understand the necessity of providing organizational support to the employees if the organization desires a high level of Employee Engagement. Further, the organizations can develop recruitment and selection procedures in such a way that it attracts and selects candidates who have better fit in terms of values with the organization. The higher the P-O Fit, the possibility of higher engagement resulting in Job satisfaction, organizational citizenship behavior and lower counter-productive work behavior. Similarly, organizations also need to increase their support that employees perceive positively in order to improve or increase their engagement at work which also results in positive outcomes. Rich et al (2010) have also stated in their research that organizations that want to improve or increase the Employee Engagement nees to focus on employees' perception of the support that they are receiving positively. Similarly, more favorable environment that offers desired support to the employees and has more fit with employees' personal values and aspirations may lead to higher Job satisfaction, OCB and diminishes level of CWB. Finally, the mediating effect of Employee Engagement on the relationship between predictor variables and outcome variables suggest that organization can actively involve in Employee Engagement activities in order to enhance the attainment of Job satisfaction, organizational citizenship behavior and while lower the counterproductive work behaviors.

Future studies could be conducted in specific industries such as banking, manufacturing, and hospitality. Similarly, longitudinal studies can also be conducted to factor in the time effect. Employee Engagement can also be tested with financial performance of the organizations as organizations are concerned about financial performances as ROI, Equity, Profit and other financial measures. 


\section{References}

Ajzen, I. (1991). The theory of planned behavior. Organizational Behavior and Human Decision Processes, 50(2), 179-211. http://dx.doi.org/10.1016/0749-5978(91)90020-T

Ariani, D. (2013). The Relationship between Employee Engagement, Organizational Citizenship Behavior, and Counterproductive Work Behavior. International Journal of Business Administration, 4(2), 46-56. http://dx.doi.org/10.5430/ijba.v4n2p46

Bennett, R., \& Robinson, S. (2000). Development of Measure of Workplace Deviance. Journal of Applied Psychology, 85, 349-360. http://dx.doi.org/10.1037/0021-9010.85.3.349

Biswas, S., \& Bhatnagar, J. (2013). Mediator Analysis of Employee Engagement: Role of Perceived Organizational Support, P-O Fit, Organizational Commitment and Job satisfaction. The journal of Decision Makers, 38(1), 27-40.

Borman, W., \& Motowidlo, S. (1993). Expanding the criterion domain to include elements of contextual performance. In N.Schmitt \& W.C. Borman (Eds). Personnel selection in organization, 71-98. http://dx.doi.org/10.12691/jbms-3-5-1

Bowen, D., Ledford, G., \& Nathan, B. (1991). Hiring for the organization, not the job. Academy of Management Executive, 5(4), 35-49. http://dx.doi.org/10.5465/AME.1991.4274747

Brief, A., \& Motowidlo, S. (1986). Prosocial organizational behaviors. Academy of Management Review, 11, 710-725. http://dx.doi.org/10.5465/AMR.1986.4283909

Camman, C., Fichman, M., Jenkins, D., \& Klesh, J. (1979). The Michigan Organizational Assessment Questionnaire. Ann Arbor, Michigan: University of Michigan.

Campbell, J. (1990). Modelling the performance predictor problem in industrial and organizational psychology. In M. Dunnette, L. Hough, \& 2nd (Ed.), Handbook of industrial and organizational psychology (Vol. 1, pp. 687-732). Palo Alto, CA: Consulting Psychologists Press.

Chhetri, S. B. (2017). Antecedents and Consequences of Job Engagement: Empirical Evidence of Bank Employees.Business Perspectives and Research, 5(2), 1-13. http://dx.doi.org/10.1177/2278533717692919

Dalal, R., Lam, H., Weiss, H., Weich, E., \& Hulin, C. (2009). A Within Approach to Work Behavior and Performance: Concurrent and Lagged Citizenship-Counter Productive Association and Dynamic Relationship with Affect and Overall Job Performance. Academy of Management Journal, 52, 10611068. http://dx.doi.org/10.5465/AMJ.2009.44636148

Edmondson, A. (1999). Psychological safety and learning behavior in work teams. Administrative Science Quarterly, 45, 350-383.

Erdugan, R. (2012). The Effect of Economic Factors on the Performance of the Australian Stock Market. Melbourne: School of Accounting and Finance, Faculty of Business and Law, Victoria University.

Gallup. (2004). International manufacturing firm: Employee Engagement. Princeton: Gallup.

Gallup. (2007). Financial services companies:Employee and customer engagement. Princeton.

George, J. M., \& Brief, A. P. (1992). Feeling good-doing good: a conceptual analysis of the mood at work-organizational spontaneity relationship. Psychological bulletin, 112(2), 310. http://dx.doi.org/10.1037/0033-2909.112.2.310

Hagedorn, L. (2000). Conceptualizing faculty Job satisfaction: Components, theories, and outcomes. New Direction for Instrumental Research, 2000(105), 5-20. DOI: http://dx.doi.org/10.1002/ir.10501

Hakanen, J., Bakker, A. B., \& \& Schaufeli, W. B. (2006). Burnout and work engagement among teachers. Journal of School Psychology, 43, 495-513. http://dx.doi.org/10.1016/j.jsp.2005.11.001

Hamid, S., \& Yahy, K. (2011). Relationship between person-job fit and person-organization fit on employee's work engagement: a study among engineers in semiconductor companies in Malaysia.

Journal of Business and Management Research, July 2017, Vol. 2, No. 1 \& 2 
International Journal of Finance and Management, 1(3), 185-254. DOI: http://dx.doi.org/10.1.1.471.4096

Harter, J., Schmidt, F., \& Hayes, T. (2002). Business unit-level relationship between employee satisfaction, Employee Engagement and business outcomes: A meta-analysis. Journal of Applied Psychology, 87, 268-279. DOI: http://dx.doi.org/10.1037//0021-9010.87.2.268

Hayes, A. (2009). Beyond Baron and Kenny:Statistical mediation analysis in New Millennium. Communication Monographs, 76, 408-420. http://dx.doi.org/10.1080/03637750903310360

Judge, T., \& Bretz, R. (1992). Effects of work values on job choice decisions. Journal of Applied Psychology, 261-271. http://dx.doi.org/10.2307/255828

Kahn, W. (1990). Psychological conditions of personal engagement and disengagement at work. Academy of Management, 33, 692-724.

Kahn, W. (1992). To be fully there: Psychological presence at work. Human Relations, 45, 321-349. http://dx.doi.org/0.1177/001872679204500402

Kralj, A. L., \& Solnet, D. J. (2011). The influence of perceived organizational support on engagement: a cross-generational investigation in the hospitality industry. 1-9.

Lee, K., \& Allen, N. (2002). Organizational Citizenship Behavior and Workplace Deviance: The Role of Affect and Cognitons. Journal of Applied Psychology, 87, 131-142. http://dx.doi.org/10.1037/0021-9010.87.1.131

Lewin, K. (1951). Field Theory in science. New York: Harper \& Row.

Luthans, F., \& Peterson, S. J. (2002). Employee Engagement and manager self-efficacy. Journal of Management Development, 21(5), 376-387. DOI: http://dx.doi.org/10.1108/02621710210426864

Maccey, W., \& Schneider, B. (2008). The meaning of Employee Engagment. Industrial \& Organizational Psychology, 1(1), 3-30. http://dx.doi.org/10.1111/j.1754-9434.2007.0002.x

MacKinnon, D. P., Lockwood, C. M., \& Williams, J. (2004). Confidence limits for the indirect: Distribution of the product and resampling method. Multivariate Behavioral Research, 39, 99-128. http://dx.doi.org/10.1207/s15327906mbr3901_4

Maslach, C., \& Leiter, M. (1997). The truth about burnout. San Francisco: Jossey-Bass.

Mathumbu, D., \& Dodd, N. (2013). Perceived Organisational Support, Work Engagement and Organizational Citizenship Behaviour of Nurses at Victoria Hospital. J Psychology, 4(2), 87-93.

May, D., Gilson, R., \& Harter, L. (2004). The psychological conditions of meaningfulness, safety and availability and the engagement of the human spirit at work. Journal of Occupational \& Organizational Psychology, 77, 11-37. http://dx.doi.org/10.1348/096317904322915892

Miles, D., Spector, P., Borman, W., \& Fox, S. (2002). Building An Integrative Model of Extra Role Work Behavior: A Comparison of Counterproductive Work Behavior with Organizational 
Citizenship Behavior. International Journal of Selection and Assessment, 10, 51-57. http://dx.doi.org/10.1177/0149206313503019

O' Reilly, C., Chatman, J., \& Cladwell, D. (1991). People and organizational culture: A profile comparison approach to assessing person-organization fit. Academy of Management Journal, 87, 487-516. http://dx.doi.org/10.2307/25640

Organ, D. W., \& Paine, J. B. (1999). A new kind of performance for industrial and organizational psychology: Recent contribution to Organizational Citizenship Behavior. International Review of Industrial and Organizational Psychology, 14, 337-368.

Perins, T. (2003). Working Today:Understanding what drives Employee Engagement. Retrieved May 3, 2014, from http://www.keepem.com/doc_files/Towers_Perrin_Talent_2003(TheFinal).pdf

Preacher, K. J., \& Hayes, A. F. (2004). SPSS and SAS procedures for estimating indirect effects in simple mediation model. Behavior Research Methods, Instruments, and Computers, 36, 717-731. http://dx.doi.org/10.3758/BF03206553

Preacher, K. J., \& Hayes, A. F. (2008). Asymptotic and resampling strategies for assessing and comparing indirect effects in multiple mediator models. Behavior Research Methods, 40, 879-891. Retrieved from http://www.afhayes.com/index.html.

Rhodes, L., \& Eisenberger, R. (2002). Perceived organizational support: A review of the literature. Journal of Applied Psychology, 87, 698-714. DOI: http://dx.doi.org/10.1037/0021-9010.87.4.698

Rich, B., LePine, J., \& Crawford, E. (2010). Job Engagement: Antecedents and effects on Job Performance. Academy of Management Journal, 53(3), 617-635. http://dx.doi.org/10.5465/AMJ.2010.51468988

Rurkkhuma, S., \& Bartlettb, K. R. (2012). The relationship between Employee Engagement and organizational citizenship behaviour in Thailand. Human Resource Development International, 15(2), 157-174. http://dx.doi.org/10.1080/13678868.2012.664693

Sackett, P. R. (2002). The structure of counterproductive work behaviors:Dimensionality and relationships with the facets of job performance. International Journal of Selection and Assessment, 10, 5-11. http://dx.doi.org/10.1177/0149206313503019

Saks, A. (2006). Antecedents and consequences of Employee Engagement. Journal of Managerial Psychology, 21(7), 600-619. http://dx.doi.org/10.1108/02683940610690169

Schaufeli, W., \& Baker, A. (2003). Schaufeli. Retrieved January 8, 2014, from http://www. schaufeli.com.

Schaufeli, W., Salanova, M., Gonalez-Roma, V., \& Baker, A. (2002). The measurement of burout and engagement: A confirmatory factor analysis approach. Journal of Happiness studies, 3, 71-92. http://dx.doi.org/10.1023/A:1015630930326

Smith, C. A., Organ, D. W., \& Near, J. P. (1983). Organizational citizenship behavior: Its nature and antecedents. Journal of Applied Psychology, 68, 665-663. http://dx.doi.org/10.1037/0021$\underline{9010.68 .4 .653}$

Spector, P., \& Fox, S. (2002). An Emotion-Centered Model of Voluntary WOrk Behavior, Some Parallels Between Counterproductive Work Behavior And Organizational Citizenship Behavior. 
Human Resource Management Review, 12, 269-292. http://dx.doi.org/10.1016/S10534822(02)00049-9

Sulea, C., Virga, D., Maricutoiu, L. P., Schaufeli, W., Dumitru, C. Z., \& Sava, F. A. (2012). Work engagement as mediator between job characteristics and positive and negative extra-role behaviors. Career Development International, 17, 188-207. http://dx.doi.org/10.1108/13620431211241054

Ugboro, I., \& Obeng, K. (2000). Top management leadership, employee empowerment,Job satisfaction and, customer satisfaction. Journal of Quality Management, 5(2), 247-272. http://dx.doi.org/10.1016/S1084-8568(01)00023-2

Xanthopoulou, D., Bakker, a. A., Schaufeli, W., \& Evangelia. (2007). The role of personal resources in the job demands-resources model. International Journal of Stress Management, 14(2), 121-141. http://dx.doi.org/10.1037/1072-5245.14.2.121

\section{Appendix-1}

Person-Organization Fit (P-O Fit).

My organization meets my major needs well.

This organization has the same values as I do with regard to concern for others

I feel that my personal values are a good fit with this organization.

Perceived Organizational Support (POS)

The organization values my contribution to its well-being.

The organization fails to appreciate any extra effort from me. (R)

The organization would ignore any complaint from me. (R)

The organization really cares about my well-being.

Even if I did the best job possible, the organization would fail to notice. (R)

The organization cares about my general satisfaction at work.

The organization shows very little concern for me. (R)

The organization takes pride in my accomplishments at work.

Employee Engagement

I work with intensity on my job

I exert my full effort to my job

I devote a lot of energy to my job

I try my hardest to perform well on my job

I strive as hard as I can to complete my job

I exert a lot of energy on my job

I am enthusiastic in my job

I feel energetic at my job

I am interested in my job

I am proud of my job 
I feel positive about my job

I am excited about my job

At work, my mind is focused on my job

At work, I pay a lot of attention to my job

At work, I focus a great deal of attention on my job

At work, I am absorbed by my job

At work, I concentrate on my job

At work, I devote a lot of attention to my job

Job satisfaction

All in all, I am satisfied with my job.

In general, I don't like working here. (R)

In general, I like working here.

\section{Organizational Citizenship Behavior}

\section{$\mathrm{OCBO}$}

Attendance at work is above the norm

Give advance notice when unable to come to work

Take undeserved work breaks (reverse-scored)

Great deal of time spent with personal phone conversations (reverse-scored)

Complain about insignificant things at work (reverse scored)

Conserve and protect organizational property

Adhere to informal rules devised to maintain order.

\section{OCBI}

Help others who have been absent

Help others who have heavy work loads

Assist supervisors with his or her work when not asked

Take time to listen to co-workers' problems and worries

Go out of my way to help new employees

Take personal interest in other employees

Pass along information to co-workers

\section{Counterproductive Work Behavior (CWB)}

Purposely did your work incorrectly

Purposely worked slowly when things needed to get done

Purposely failed to follow instructions

Came to work late without permission

Stayed home from work and said you were sick when you weren't

Taken a longer break than you were allowed to take

Left work earlier than you were allowed to 
Predictors and Outcomes of Employee Engagement 33

Journal of Business and Management Research, July 2017, Vol. 2, No. 1 \& 2 